\title{
Penerapan Metode Permainan untuk Meningkatkan Hasil dan Minat Belajar Matematika Siswa SMP
}

\author{
Sri Priyaningsih ${ }^{1, *}$, Suyono $^{2}$ \\ 1,2SMP Negeri 1 Karangtengah Kabupaten Cianjur \\ * sripriyaningsih2019@gmail.com
}

\begin{tabular}{|l|l|l|l|}
\hline Received : 11-09-2020 & Revised: 07-10-2020 & Accepted: 19-10-2020 & Published: 05-12-2020 \\
\hline
\end{tabular}

\begin{abstract}
ABSTRAK
Penelitian ini dilatarbelakangi oleh rendahnya hasil dan minat belajar matematika siswa. Minat belajar memiliki pengaruh yang besar terhadap hasil belajar, karena jika bahan pelajaran yang dipelajari tidak sesuai dengan minat siswa, siswa tidak akan belajar dengan baik. Jika belajar tanpa disertai minat, siswa akan malas dan tidak akan mendapatkan kepuasan dalam mengikuti pembelajaran. Tujuan penelitian ini adalah untuk meningkatkan hasil dan minat belajar siswa menggunakan metode permainan pada kelas IX di SMPN 1 Karangtengah Cianjur. Metode penelitian yang digunakan adalah PTK (Penelitian Tindakan Kelas). Materi yang disampaikan berkenaan dengan materi kesebangunan meliputi menjelaskan bentuk-bentuk bangun datar. Penelitian ini dilakukan dalam dua siklus, untuk siklus ke-1 memiliki 1 pertemuan dan siklus ke-2 memiliki 2 pertemuan. Teknik pengumpulan data menggunakan angket dan tes. Berdasarkan hasil penelitian, disimpulkan bahwa penerapan metode permainan dapat meningkatkan hasil belajar siswa dari rata-rata siklus I sebesar 55\% menjadi $70 \%$ di siklus II. Selain itu, dapat meningkatkan minat belajar siswa dari rata-rata di siklus I sebesar 71,40\% menjadi 76,62\% di siklus II.
\end{abstract}

Kata Kunci: minat belajar, hasil belajar, metode permainan

\begin{abstract}
This research is motivated by the low results and interest in learning mathematics students. Learning interest has a great influence on learning outcomes, because if the learning material being studied is not in accordance with student interests, students will not learn well. If learning without interest, students will be lazy and will not get satisfaction in following the lesson. The purpose of this study was to improve student learning outcomes and interest using the game method in class IX at SMPN 1 Karangtengah Cianjur. The research method used was PTK (Classroom Action Research). The material presented with regard to similarity materials includes explaining the forms of flat shapes. This research was conducted in two cycles, for the 1st cycle had 1 meeting and the 2nd cycle had 2 meetings. Data collection techniques used questionnaires and tests. Based on the research results, it was concluded that the application of the game method could improve student learning outcomes from an average of 55\% in cycle I to $70 \%$ in cycle II. In addition, it can increase students' interest in learning from the average in cycle I of $71.40 \%$ to $76.62 \%$ in cycle II.
\end{abstract}

Keywords: interest in learning, learning outcomes, game methods

\section{PENDAHULUAN}

Hasil penelitian psikologi menunjukan bahwa kurangnya minat belajar dapat mengakibatkan kurangnya rasa ketertarikan pada suatu bidang tertentu, bahkan dapat melahirkan sikap penolakan kepada guru (Kurniasari \& Rahmawati, 2016; Rahmawati, 
2018). Minat belajar besar sekali pengaruhnya terhadap hasil belajar sebab dengan minat seeorang akan melakukan sesuatu yang diminatinya. Sebaliknya tanpa minat seseorang tidak mungkin melakukan sesuatu. Misalnya seorang anak menaruh minat terhadap bidang kesenian, maka ia akan berusaha untuk mengetahui lebih banyak tentang kesenian (Sari, fiska Komala., Farida., \& Syazali, 2016).

Minat belajar siswa dalam beberapa penelitian menjadi faktor utama dalam menentukan hasil belajar siswa pada mata pelajaran matematika (Septian, Suwarman, Monariska, \& Sugiarni, 2020). Pada hasil penelitian sebelum-sebelumnya, hasil belajar siswa dapat ditingkatkan dengan menggunakan metode permainan dan metode lainnya (Imansyah, Wibawa, \& Widiyaningtyas, 2018; Kidi et al., 2017). Mengapa menggunakan metode permainan dalam penelitian ini, karena permainan mampu meningkatkan minat belajar siswa sehingga mempengaruhi terhadap hasil belajar (Oktaviani, Sulistya Dewi, \& ., 2019; Yuliati, Siregar, \& Sari, 2017). Pembedanya dengan penelitian lainnya yaitu hasil belajar siswa yang mengukur tentang kemampuan matematikanya di materi kesebangunan yang dianggap sulit oleh siswa.

Guru harus menciptakan metode belajar yang menyenangkan untuk membangkitkan semangat belajarnya (Maskur et al., 2020; Septian, Darhim, \& Prabawanto, 2020). Minat belajar siswa dapat ditumbuhkan oleh guru dengan memotivasi siswa tentang pentingnya pembelajaran tersebut. Seorang guru yang profesional harus dapat menciptakan pembelajaran yang aktif, inovatif, kreatif, efektif dan menyenangkan supaya proses belajar lebih menghasilkan dan menarik bagi siswanya (Rahmi, 2015). Model pembelajaran yang menarik bagi siswa adalah melalui permainan (Imansyah et al., 2018; Pratama \& Setyaningrum, 2018). Permainan dapat menjadi pilihan guru untuk menarik perhatian siswa .

Banyak metode yang dapat digunakan oleh guru dalam pembelajaran, diantaranya: (1) ceramah; (2) demonstrasi; (3) eksperimen (4) diskusi (5) bermain peran, (6) simulasi dan (7) bermain peran. Berdasarkan metode-metode yang ada diperlukan kejelian dan ketelitian guru dalam menentukan metode-metode pembelajaran yang sesuai dengan karakteristik siswa, materi pembelajaran, dan kondisi sekolah (Darmansyah, HAlidjah, \& Margiati, 2013; Sadiyyah, Gustiana, Panuluh, \& Sugiarni, 2019).

Permainan dapat berfungsi memberikan pencerahan saat mengalami kejenuhan, menanamkan materi dalam ingatan menjadi lebih lama, dan juga dapat berfungsi sebagai penguat dalam membuat kesimpulan diakhir pertemuan. Dengan games, kelas akan 
menjadi lebih hidup, suasana belajar penuh ceria, semangat. Selain itu, siswa akan menjadi percaya diri dan pro aktif mengikuti pelajaran (Junedi \& Sari, 2020; Mulyasari, 2018). Belajar dengan permainan lebih memungkinkan anak mengembangkan konsep yang didasarkan pada klasifikasi dan mengkontruksi kategori melalui tindakan mereka sendiri (Riptyawati, 2014).

Tujuan penelitian ini untuk mengetahui peningkatan hasil dan minat belajar matematika siswa dengan menggunakan metode permainan. Berdasarkan rumusan masalah di atas, maka tujuan yang hendak dicapai peneliti dalam penelitian ini adalah mengetahui sejauh mana peningkatan hasil belajar matematika dan minat belajar siswa dengan menggunakan metode permainan.

\section{METODE PENELITIAN}

Penelitian ini merupakan Penelitian Tindakan Kelas (PTK) yang dilaksanakan dalam siklus-siklus dan akan dihentikan jika sudah memenuhi indikator keberhasilan. Tiap-tiap siklus merupakan proses pengkajian berdaur yang terdiri dari empat tahap. Menurut Kemmis dan Taggart, penelitian tindakan dalam satu siklus terdiri dari empat komponen yang meliputi : perencanaan (planning), tindakan/aksi (acting), pengamatan (observing), dan refleksi (reflecting) (Soleh, Setiawan, \& Haqi, 2020).

Apabila hasil dari siklus yang pertama belum sesuai yang diharapkan yaitu belum memenuhi indikator keberhasilan, maka dilanjutkan dengan siklus selanjutnya ini didasarkan pada hasil refleksi siklus sebelumnya (Septian \& Komala, 2019).

Subjek dalam penelitian ini terdiri dari dua macam yaitu subjek pelaku tindakan dan subjek penerima tindakan. Subjek pelaku tindakan dalam penelitian ini adalah peneliti yang dibantu guru matematika kelas IX A SMPN 1 Karangtengah Cianjur sebagai kolaborator dan untuk subjek penerima tindakan adalah siswa kelas IX A SMPN 1 Karangtengah Cianjur. Materinya tentang kesebangunan.

Instrumen penelitian dalam penelitian ini meliputi peneliti, tes, dan angket. Teknik analisis data dalam penelitian ini adalah reduksi data, triangulasi, analisis dan penyajian data. Analisis data dilakukan juga secara deskriptif kuantitatif dengan menggunakan frekuensi jawaban siswa. 
HASIL DAN PEMBAHASAN

Hasil Belajar Siswa

Tabel 1. Hasil Test Belajar Siswa Siklus I dan II

\begin{tabular}{|c|c|c|c|c|c|c|}
\hline & \multicolumn{6}{|c|}{ Hasil Belajar } \\
\hline & \multirow{2}{*}{$\begin{array}{c}\text { Nilai } \\
\text { Siklus I }\end{array}$} & \multicolumn{2}{|c|}{ Keterangan } & \multirow{2}{*}{$\begin{array}{c}\text { Nilai } \\
\text { Siklus II }\end{array}$} & \multicolumn{2}{|c|}{ Keterangan } \\
\hline & & $\begin{array}{l}\text { Belum } \\
\text { Tuntas }\end{array}$ & Tuntas & & $\begin{array}{l}\text { Belum } \\
\text { Tuntas }\end{array}$ & Tuntas \\
\hline Rata-Rata & 73,75 & & & 82,50 & & \\
\hline Persentase & & $45 \%$ & $55 \%$ & & $30 \%$ & $70 \%$ \\
\hline
\end{tabular}

Pada Tabel 1, setelah dilakukan analisis data hasil tes siklus 1, diperoleh nilai ratarata siswa sebesar 73.75, siswa yang tuntas sebanyak 11 siswa dengan presentase $55 \%$ dari 20 siswa, siswa yang tidak tuntas sebanyak 9 siswa $45 \%$ dari 20 siswa, dengan nilai tertinggi 100 dan nilai terendah 30. Sedangkan pada siklus II, diperoleh nilai rata-rata siswa sebesar 82,5, siswa yang tuntas sebanyak 14 siswa dengan presentase $70 \%$ dari 20 siswa, siswa yang tidak tuntas sebanyak 6 siswa 30\% dari 20 siswa, dengan nilai tertinggi 100 dan nilai terendah 45. Kesimpulannya, Penerapan metode permainan dapat meningkatkan hasil belajar siswa dari rata-rata siklus I sebesar 55\% menjadi 70\% di siklus II.

Berdasarkan Tabe1 1, bahwa siswa yang mendapatkan nilai kurang dari KKM adalah siswa yang memliki kesulitan menjawab soal pada nomor 4 dan 5, setelah penulis melakukan analisis bahwa siswa pada waktu kegiatan pembelajaran izin untuk ke belakang (toilet) dan tidak kembali ke kelasnya ketika diberikan penjelasan materi, sehingga siswa tersebut merasa kesulitan untuk mengerjakan soal no 4 dan 5.

Pada siklus I, siswa yang kurang memiliki rasa suka saat pembelajaran matematika menggunakan metode permainan karena siswa terlihat pasif dikelas sehingga saat kegiatan belajar siswa tersebut belum terbiasa untuk belajar matematika menggunakan metode permainan. Karena belajar matematika menggunakan metode permainan diperlukan siswa yang aktif. Sedangkan pada siklus II, siswa sudah berdadaptasi dengan cepat sehingga tumbuh rasa suka dengan metode permainan, menyenangkan, tidak jenuh, sehingga materi pelajaran lebih mudah diserap siswa (Junedi \& Sari, 2020; Mulyasari, 2018). Selain itu, kerjasama dan komunikasi yang terjalin antara guru dengan siswa dan siswa dengan siswa (Putra, 2017). Sejalan dengan penelitian sebelumnya, bahwa belajar dengan permainan lebih memungkinkan anak mengembangkan konsep yang didasarkan pada klasifikasi dan 
mengkontruksi kategori melalui tindakan mereka sendiri (Riptyawati, 2014; Sanusi, Septian, \& Inayah, 2020).

\section{Minat Belajar Siswa}

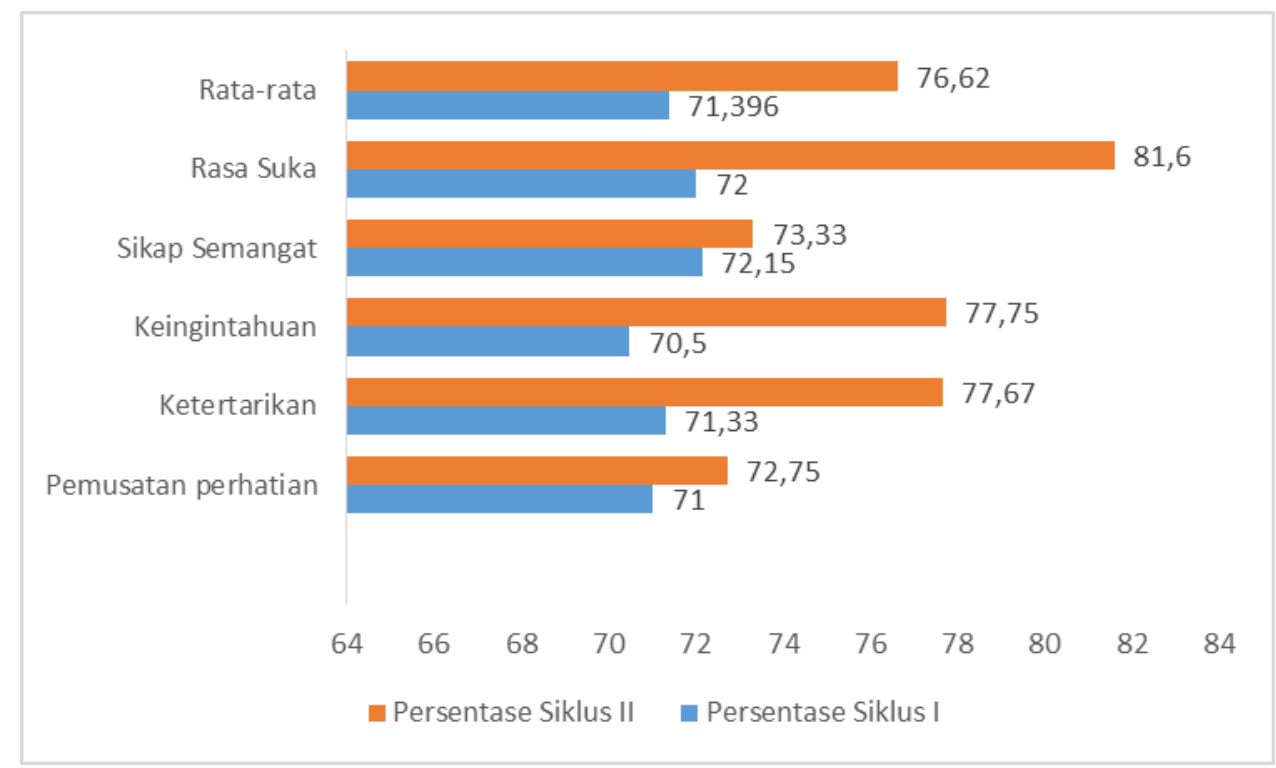

Gambar 2. Persentase Minat Belajar Siswa Siklus I dan II

Pada Gambar 2, menunjukkan bahwa siklus 1 diperoleh nilai rata-rata 71.40\% , indikator ke-1 berisi tentang "Pemusatan Perhatian siswa terhadap pembelajaran matematika" ada di butir 17, 23, 24 dan 25 dengan skor $71.00 \%$, indikator ke-2 berisi tentang "ketertarikan/kecenderungan hati siswa terhadap materi pelajaran matematika yang akan dipelajari" ada di butir ke 2, 6, 7, 8, dan 16 dengan skor $71.33 \%$ indikator ke-3 berisi tentang "keingintahuan/keinginan siswa untuk mengetahui dan mempelajari materi pelajaran matematika" ada di butir 18, 20, 21, dan 22 dengan skor $70.50 \%$, indikator ke-4 berisi tentang "sikap semangat/antusias/gairah siswa untuk mempelajari materi pembelajaran matematika" ada di butir 4, 5, 9, 12, 14, dan 15 dengan skor $72.17 \%$, indikator ke-5 berisi tentang "Rasa suka/senang siswa saat mengikuti pelajaran matematika" ada dibutir 1, 3, 10, 11, 13, dengan skor $72.00 \%$. Persentase terbesar ada di indikator ke-4 yaitu $72.17 \%$ tentang "Sikap Semangat", dan terendah berada di indikator ke-3 yaitu dengan skor $70.59 \%$ tentang "keingintahuan"

Pada siklus I, siswa memiliki sikap semangat yang tinggi karena siswa merasa jenuh belajar matematika dengan cara konvensional sehingga saat belajar matematika menggunakan metode permainan, siswa lebih termotivasi dan semangat saat belajar (Kirci \& Kahraman, 2015). Sedangkan siswa yang memiliki keingintahuan rendah karena siswa 
pasif saat dikelas sehingga saat belajar menggunakan metode permainan siswa memilih diam dari pada bertanya sesuatu yang mereka tidak pahami (Mohd, Shahbodin, Sedek, \& Samsudin, 2020; Pramuditya, Noto, \& Purwono, 2018).

Pada Gambar 2, hasil angket minat belajar siswa siklus II diperoleh nilai rata-rata $76.62 \%$, indikator ke-1 berisi tentang "Pemusatan Perhatian terhadap pembelajaran matematika" ada di butir 17, 23, 24 dan 25 dengan skor 72.75\%, indikator ke-2 berisi tentang "ketertarikan/kecenderungan hati siswa terhadap materi pelajaran matematika yang akan dipelajari" ada di butir ke 2, 6, 7, 8, dan 16 dengan skor $77.67 \%$ indikator ke-3 berisi tentang "keingintahuan/keinginan siswa untuk mengetahui dan mempelajari materi pelajaran matematika" ada di butir 18, 20, 21, dan 22 dengan skor $76.00 \%$, indikator ke-4 berisi tentang "sikap semangat/antusias/gairah siswa untuk mempelajari materi pembelajaran matematika" ada di butir 4, 5, 9, 12, 14, dan 15 dengan skor $73.33 \%$, indikator ke-5 berisi tentang "Rasa suka/senang siswa saat mengikuti pelajaran matematika" ada dibutir $1,3,10,11,13$, dengan skor $82.00 \%$. Persentase terbesar ada di indikator ke-5 yaitu $82.60 \%$ tentang "Rasa Suka", dan terendah berada di indikator ke-1 yaitu $72.75 \%$ yaitu tentang "Pemusatan Perhatian"

Pada siklus II, siswa memiliki rasa suka yang tinggi karena siswa merasa jenuh belajar matematika dengan cara konvensional sehingga saat belajar matematika menggunakan metode permainan, siswa lebih termotivasi dan semangat saat belajar, skor terendah berada si indikator 1 karena dalam indikator 1 berisi tentang pemusatan perhatian dimana salah satu isi angketnya yaitu "Memperhatikan penjelasan guru mengenai materi matematika membuat saya mengantuk" sehingga mereka lebih senang belajar sambil bermain agar tidak jenuh dan mengantuk. Minat belajar siswa dapat ditumbuhkan oleh guru dengan memotivasi siswa tentang pentingnya pembelajaran tersebut (Sari, fiska Komala., Farida., \& Syazali, 2016). Seorang guru yang profesional harus dapat menciptakan pembelajaran yang aktif, inovatif, kreatif, efektif dan menyenangkan supaya proses belajar lebih menghasilkan dan menarik bagi siswanya (Fatwa, Septian, \& Inayah, 2019; Sanusi et al., 2020).

\section{KESIMPULAN}

Kesimpulan hasil penelitian ini yaitu penerapan metode permainan dapat meningkatkan hasil belajar siswa dan penerapan metode permainan dapat meningkatkan minat belajar siswa. Terjadi peningkatan rata-rata nilai tes hasil belajar siswa dari siklus I 
ke siklus II. Selain itu, minat belajar siswa juga mengalami peningkatan dari siklus I ke siklus II.

\section{REFERENSI}

Darmansyah, S., HAlidjah, S., \& Margiati, K. (2013). Peningkatan Aktivitas dan Hasil Belajar Siswa dalam Pembelajaran Ilmu Pengetahuan Alam dengan Menggunakan Metode Eksperimen.

Fatwa, V. C., Septian, A., \& Inayah, S. (2019). Kemampuan Literasi Matematis Siswa melalui Model Pembelajaran Problem Based Instruction. Mosharafa: Jurnal Pendidikan Matematika, 8(3), 389-398.

Imansyah, P. B., Wibawa, A. P., \& Widiyaningtyas, T. (2018). Android Game for Typing Skill Evaluation. Letters in Information Technology Education (LITE), 1(1), 14-17. https://doi.org/10.17977/um010v1i12018p014

Junedi, B., \& Sari, E. P. (2020). Penggunaan Multimedia Pembelajaran Interaktif terhadap Kemampuan Koneksi Matematis Siswa Kelas XI MIPA SMA. Prisma, 9(1), 87. https://doi.org/10.35194/jp.v9i1.915

Kidi, N., Kanigoro, B., Salman, A. G., Prasetio, Y. L., Lokaadinugroho, I., \& Sukmandhani, A. A. (2017). Android Based Indonesian Information Culture Education Game. Procedia Computer Science, 116, 99-106. https://doi.org/10.1016/j.procs.2017.10.015

Kirci, P., \& Kahraman, M. O. (2015). Game based education with android mobile devices. 6th International Conference on Modeling, Simulation, and Applied Optimization, ICMSAO 2015 - Dedicated to the Memory of Late Ibrahim El-Sadek. https://doi.org/10.1109/ICMSAO.2015.7152220

Kurniasari, I. D., \& Rahmawati, D. (2016). Pengaruh Minat Menjadi Guru Dan Praktik Pengalaman Lapangan ( Ppl ) Terhadap Kesiapan Mengajar. Jurnal Kajian Pendidikan Akuntansi Indonesia Edisi 2, 1-14.

Maskur, R., Sumarno, Rahmawati, Y., Pradana, K., Syazali, M., Septian, A., \& Palupi, E. K. (2020). The effectiveness of problem based learning and aptitude treatment interaction in improving mathematical creative thinking skills on curriculum 2013. European Journal of Educational Research, 9(1), 375-383. https://doi.org/10.12973/eu-jer.9.1.375

Mohd, C. K. N. C. K., Shahbodin, F., Sedek, M., \& Samsudin, M. (2020). Game based learning for autism in learning mathematics. International Journal of Advanced Science and Technology, 29(5), 4684-4691.

Mulyasari, Y. (2018). Inductive Approach Implementation to Improve The Mathematichal Reasoning, Problem-Solving, and Self-Concept of Junior High School Students in Karawang District. PRISMA, 7(2), 186. https://doi.org/10.35194/jp.v7i2.378

Oktaviani, T., Sulistya Dewi, E. R., \& . K. (2019). Penerapan Pembelajaran Aktif dengan Metode Permainan Bingo untuk Meningkatkan Hasil Belajar Matematika. Mimbar Ilmu, 24(1). https://doi.org/10.23887/mi.v24i1.17409

Pramuditya, S. A., Noto, M. S., \& Purwono, H. (2018). Desain Game Edukasi Berbasis Android pada Materi Logika Matematika. JNPM (Jurnal Nasional Pendidikan Matematika), 2(2), 165. https://doi.org/10.33603/jnpm.v2i2.919

Pratama, L. D., \& Setyaningrum, W. (2018). Game-Based Learning: The effects on student cognitive and affective aspects. Journal of Physics: Conference Series, 1097(1). https://doi.org/10.1088/1742-6596/1097/1/012123

Putra, J. D. (2017). Learning Cycle 5E Dalam Meningkatkan Kemampuan Komunikasi Matematis Dan Self-Regulated Learning Matematika. Prisma, 6(1), 43-56. https://doi.org/10.35194/jp.v6i1.27 
Rahmawati, N. I. (2018). Pemanfaatan ICT dalam Meningkatkan Kemampuan Literasi Matematika. PRISMA, 1, 381-387.

Rahmi, R. (2015). Menciptakan Pembelajaran Matematika yang Kreatif dan Menyenangkan. Jurnal Pelangi, 6(1). https://doi.org/10.22202/jp.v6i1.292

Riptyawati, E. (2014). Upaya Meningkatkan Hasil Belajar Who Wants To Be a Smart Student Pada Siswa Kelas Ix F Smp Negeri 1 Bandungan Tahun 2013 / 2014. 4, 6378.

Sadiyyah, R., Gustiana, M., Panuluh, S. D., \& Sugiarni, R. (2019). Pengembangan Lembar Kerja Siswa (Lks) Dengan Pendekatan Inkuiri Terbimbing Berbasis Mobile Learning Untuk Mengoptimalkan Kemampuan Berpikir Kritis Matematis. Prisma, 8(1), 80. https://doi.org/10.35194/jp.v8i1.616

Sanusi, A. M., Septian, A., \& Inayah, S. (2020). Kemampuan Berpikir Kreatif Matematis dengan Menggunakan Education Game Berbantuan Android pada Barisan dan Deret. Mosharafa: Jurnal Pendidikan Matematika, 9(September), 511-520.

Sari, fiska Komala., Farida., \& Syazali, M. (2016). Pengembangan Media Pembelajaran (Modul) Berbantuan Geogebra Pokok Bahasan Turunan Tahun Pelajaran 2015/2016 (Kelas XI SMA Negeri 1 Rumbia Lampung Tengah). Jurnal Al-Jabar, 7(2), 16-33.

Septian, A., Darhim, \& Prabawanto, S. (2020). Geogebra in integral areas to improve mathematical representation ability. Journal of Physics: Conference Series, 1613(1), 12035. https://doi.org/10.1088/1742-6596/1613/1/012035

Septian, A., \& Komala, E. (2019). Kemampuan Koneksi Matematik dan Motivasi Belajar Siswa dengan Menggunakan Model Problem-Based Learning (PBL) Berbantuan Geogebra di SMP. PRISMA, 8(1), 1-13. https://doi.org/10.35194/jp.v8i1.438

Septian, A., Suwarman, R. F., Monariska, E., \& Sugiarni, R. (2020). Somatic , auditory , visualization, intellectually learning assisted by GeoGebra to improve student's mathematical representation skills. Journal of Physics: Conference Series, 1657, 12023. https://doi.org/10.1088/1742-6596/1657/1/012023

Soleh, E. R. A., Setiawan, W., \& Haqi, R. (2020). Upaya Meningkatkan Kemampuan Komunikasi Matematis dan Aktivitas Belajar Siswa Menggunakan Model Problem Based Learning. Prisma, 9(1), 1. https://doi.org/10.35194/jp.v9i1.798

Yuliati, S. R., Siregar, R., \& Sari, R. P. (2017). Permainan Polydron dalam Proses Pembelajaran Matematika di Sekolah Dasar. PARAMETER: Jurnal Pendidikan Universitas Negeri Jakarta, 29(2), 223-230. https://doi.org/10.21009/parameter.292.10 